\title{
Seismic properties of naturally deformed quartzites of the Alaknanda valley, Garhwal Himalaya, India
}

\author{
Ruchika Sharma Tandon ${ }^{1, *}$, Vikram Gupta ${ }^{2}$ and Koushik Sen ${ }^{2}$ \\ ${ }^{1}$ National Geotechnical Facility, 11-C, Circular Road, Dehradun 248 001, India. \\ ${ }^{2}$ Wadia Institute of Himalayan Geology, Dehradun 248 001, India. \\ *Corresponding author.e-mail: ruchika_ddn@yahoo.co.in
}

The present contribution summarizes the results of a study focusing on the influence of quartz microstructures on the seismic wave velocities in the quartzites of the Garhwal Himalaya. Quartzites being monomineralic were chosen for the present study so as to nullify the effect of other mineral constituents on the seismic velocity. Samples were collected from different tectonic settings of the Higher and Lesser Himalayas which are separated from one another by the major tectonic zone 'Main Central Thrust' (MCT). These are mainly Pandukeshwar quartzite, Tapovan quartzite and Berinag quartzite. The samples of Berinag quartzite were collected from near the klippen and the thrust, termed as Alaknanda Thrust. The vast differences in microstructures and associated seismic wave velocities have been noted in different quartzites. It has also been observed that quartzites of the MCT zone and Alaknanda Thrust have higher seismic velocities. This is because of their coarse-grained nature of the rocks as evidenced by the strong positive relation between seismic velocities and grain area. The coarsening is either due to the operation of grain boundary migration and grain area reduction process or high aspect ratio/shape preferred orientation. The quartzites located around Nandprayag Klippen have undergone static recrystallization and exhibit the lowest seismic wave velocities.

\section{Introduction}

Among all the common rock forming minerals, quartz is the most sensitive to any change in prevailing stress, temperature and deformation conditions. Past studies have shown that quartz develops distinctive microstructural features for varying stress, temperature and strain rate (Hirth and Tullis 1992; Stipp et al. 2002, 2010; Stipp and Kunze 2008). These microstructures are produced due to the operation of different mechanisms of recrystallization. There are mainly two types of recrystallization, i.e., static and dynamic (figure 1). Static recrystallization is characterized by isotropic stress distribution, whereby temperature is sufficiently high such that the grain boundaries could migrate and hence produce the 'Foam Texture'. On the other hand, in dynamic recrystallization the nucleation and growth of new grains occur during deformation. There are mainly three types of mechanism of dynamic recrystallization, viz., bulging recrystallization (BLG), subgrain rotation (SGR) and grain boundary migration (GBM) which produce characteristic microstructures (figure 1). After ceasing of dynamic recrystallization, the grain boundary area reduction (GBAR) process become dominant and lead to the approach of equilibrium fabric, i.e., polygonal texture in which vertex of grains tend to make triple junction. There have been several attempts in the past, where quartz microstructures have been used to assess the deformation conditions in naturally deformed

Keywords. Quartz; microfabric; seismic velocity; quartzite; Himalaya. 


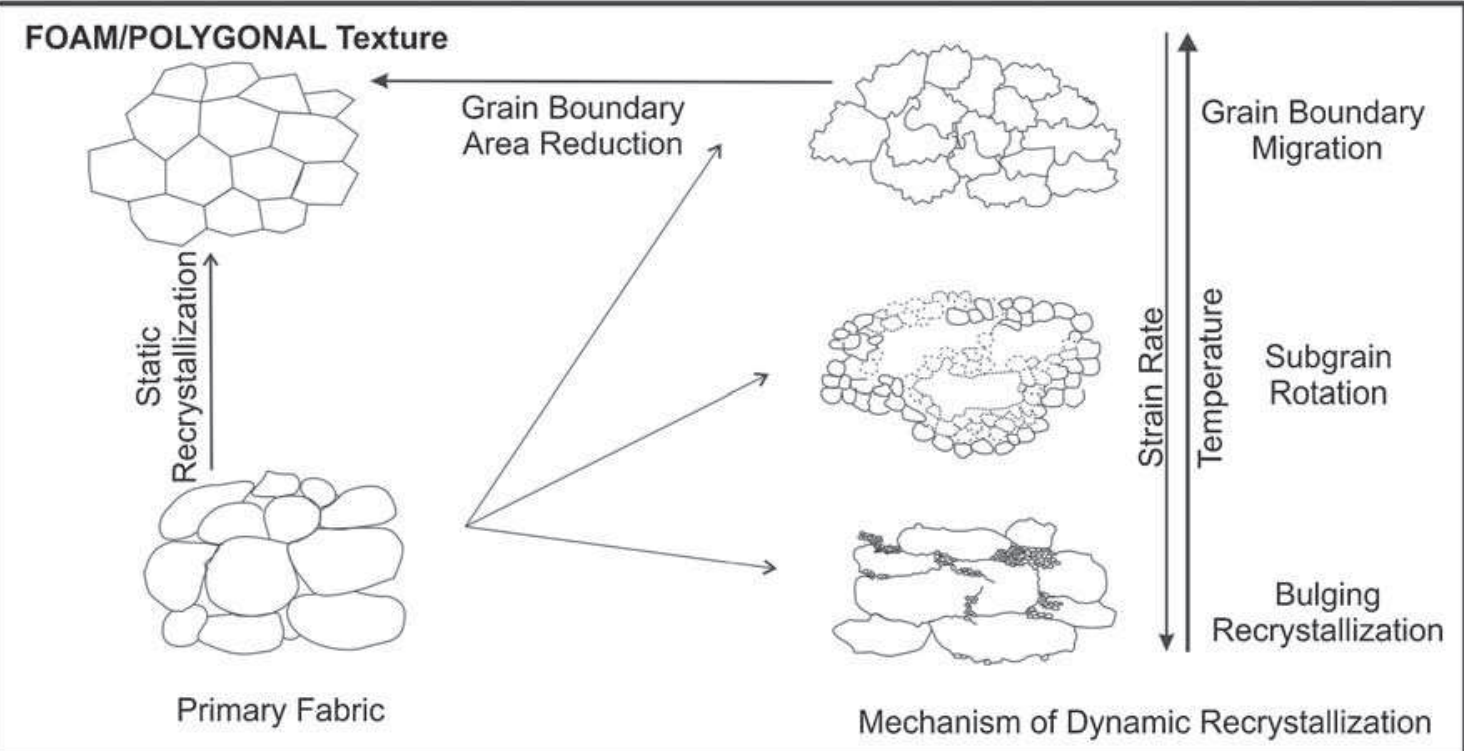

Figure 1. Characteristic microstructures produced in quartz due to different mechanisms of dynamic recrystallization and the static recrystallization.

rocks associated with major tectonic units (White 1973, 1977, 1979; Garcia Celma 1982; Jessell 1987; Kruhl 1996; Vernon et al. 2004).

It has been well established that the propagation of seismic velocities in a rock is the function of various intrinsic properties, i.e., mineralogical constituents, grain shape, grain size, grain orientation, porosity, presence of fluids, etc., as well as the extrinsic properties, i.e., stress and temperature. There exists a wealth of data on the effect of extrinsic parameters on the seismic wave velocity for most of the rock types (Birch 1960; Jackson and Arculus 1984; Burke and Fountain 1990; Christensen and Mooney 1995; Parsons et al. 1995; Zappone et al. 2000; Kitamura et al. 2003; Nishimoto et al. 2005). However, study on the effect of various intrinsic parameters on seismic wave velocity is limited, particularly in the Himalaya (Gogte and Ramana 1982; Sharma et al. 2011; Gupta and Sharma 2012; Tandon and Gupta 2013). This is primarily due to the mineralogical and textural heterogeneity of natural rocks which hinders the assessment of the effect of a particular parameter on the seismic wave velocity in a given rock.

The objective of the present study is to assess the control of textural/microstructural properties of quartz on its seismic velocity. To nullify the effect of any other mineral, monomineralic to nearly monomineralic natural quartzites were chosen from different tectonic units of the Garhwal Himalaya. The Garhwal Himalaya is characterized by the presence of quartzites of both sedimentary and metamorphic origin. These quartzites are, in turn, associated with some major thrust zones of the Garhwal Himalaya. In the present study, we have attempted to understand (1) the effect of quartz microstructures on the seismic velocity of natural quartzites and, (2) the development of these textures in terms of tectonics of major thrust zones of the Garhwal Himalaya.

\section{Geological framework of the study area}

The study area is located in the Garhwal Himalaya along the Alaknanda river and its adjoining river valleys. It lies between latitudes $30^{\circ} 15^{\prime}-30^{\circ} 44^{\prime} \mathrm{N}$ and longitudes $78^{\circ} 25^{\prime}-79^{\circ} 45^{\prime} \mathrm{E}$ and covering a stretch of about $150 \mathrm{~km}$ along the river. It displays succession of the Lesser Himalaya (Garhwal Group) and Higher Himalaya (Central Crystalline) which are tectonically separated from one another by the 'Main Central Thrust' (MCT) (figure 2). The MCT is one of the major north dipping intercontinental thrusts resulting of continentcontinent collision. The upper contact of the zone is designated as 'Vaikrita Thrust' and the lower the 'Munsiari Thrust' (figure 2). The higher Himalayan rocks in the study area occupy the northernmost part of the Alaknanda valley and are exposed between Helang and Badrinath (figure 2). It is divisible into 'Badrinath Formation' comprising gneisses and schists, 'Pandukeshwar Formation' comprising micaceous-quartzite, 'Joshimath Formation' comprising mylonites and augen gneiss and the 'Tapovan Formation' comprising quartzite and garnet-mica schist. Further south, the lesser Himalayan rocks are exposed between Helang and $\sim 5 \mathrm{~km}$ west of Kaliyasaur (figure 2). It is differentiated into 'Deoban Formation', 


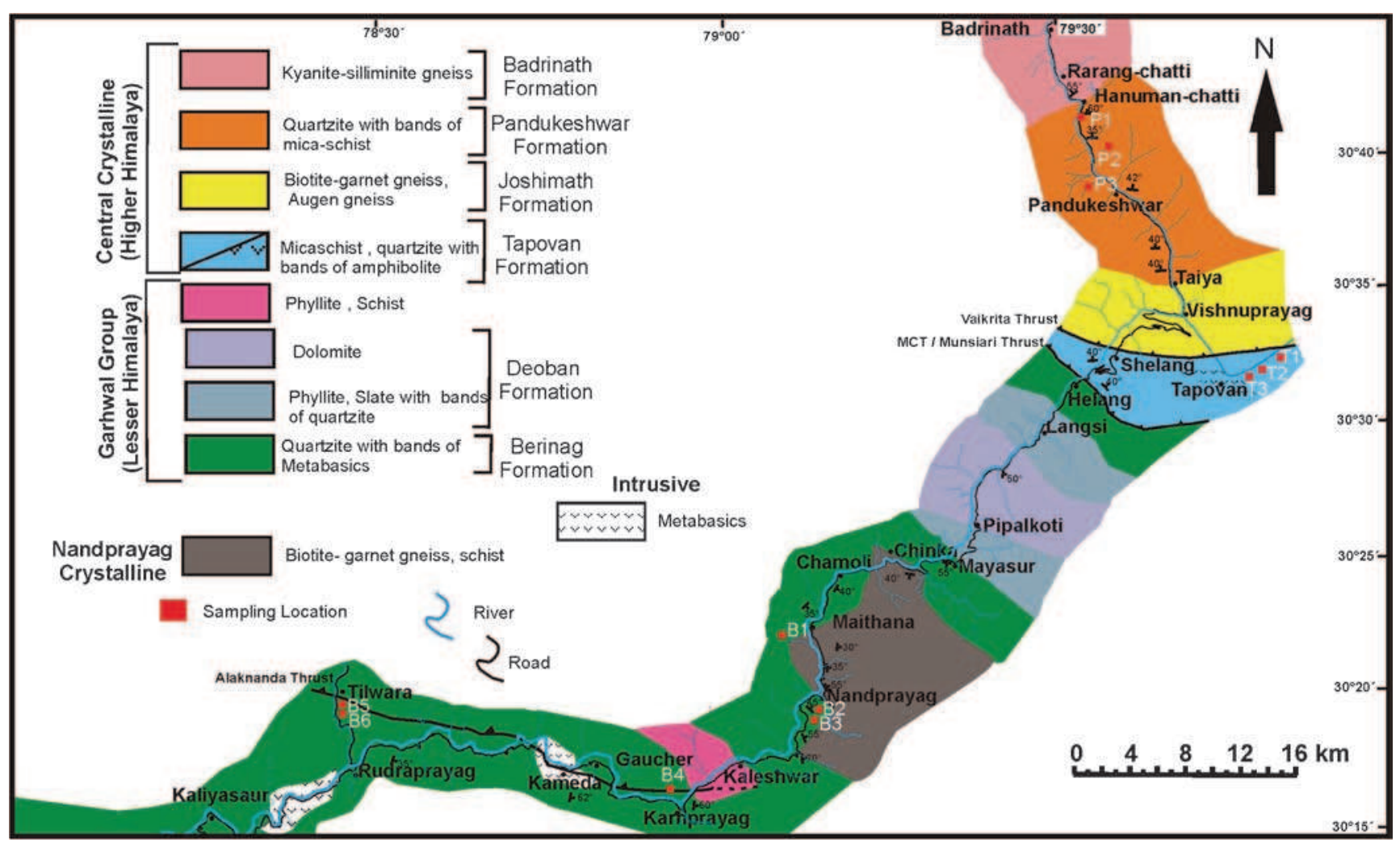

Figure 2. Geological map of the study area. Location of the samples taken for the present study has been depicted.

comprising mainly of dolomite with bands of phyllite, slate and occasionally quartzite and 'Berinag Formation', comprising quartzite and metabasics. At places, the Berinag Formation encompasses a highly crushed zone produced due to the Alaknanda Thrust which is assumed to be the latest structure in the study area (figure 2). The thickness of the crushed zone is highly variable ranging from 0.5 to $\sim 2.0 \mathrm{~km}$ and its length is $\sim 45 \mathrm{~km}$. It is exposed near village Tilwara, Kameda, Gaucher and Kaleshwar. In addition, the Higher Himalayan rocks have been encountered between Maithana and Nandprayag in the form of klippen (figure 2). It mainly comprises of mica-schist and biotite-gneiss.

\section{Field overview of quartzites}

\subsection{Pandukeshwar quartzite}

The Pandukeshwar quartzite exposed between Hanuman-Chatti and Taiya Bridge is regularly bedded, flaggy, massive, laminated and well foliated quartzite (figure 3a). It is interbedded with garnet biotite schist. The general trend of foliation is $\mathrm{E}-\mathrm{W}$ with northerly dip. The dip amount varies from $40^{\circ}$ to $45^{\circ}$.

\subsection{Tapovan quartzite}

The Tapovan quartzite, exposed around Tapovan in the Dhauliganga river valley (tributary of Alaknanda) is off-white to light green in colour, thickly bedded and mylonitized in nature. At places, it is highly leached and weathered. It is intensively folded near the MCT (figure 3b). The general trend of the foliation is WNW-ESE with NNE dip. The dip amount varies from $40^{\circ}$ to $45^{\circ}$.

\subsection{Berinag quartzite}

The Berinag quartzite is exposed in two sections, i.e., between Helang and north of Langsi and Chinka and west of Kaliyasaur. It is massive, dull white to purple and purplish pink in colour. It is thickly-bedded with individual beds ranging from $30 \mathrm{~cm}$ to more than one meter. Cross-bedding (figure 3c) and ripple marks are noted in the entire length of this formation. On the margin of Nandprayag Klippen, it is interbedded with mica schist and gneiss (figure $3 \mathrm{~d}$ ). An intense zone of crushing has been noted in the area affected by E-W running 'Alaknanda Thrust' (figure 3e). Quartzite in this zone is highly shattered (figure 3f). The strike of the rocks in the south of the 'Alaknanda Thrust' rotates between $\mathrm{N}-\mathrm{S}$ and $\mathrm{NNE}-\mathrm{SSW}$, whereas it is 

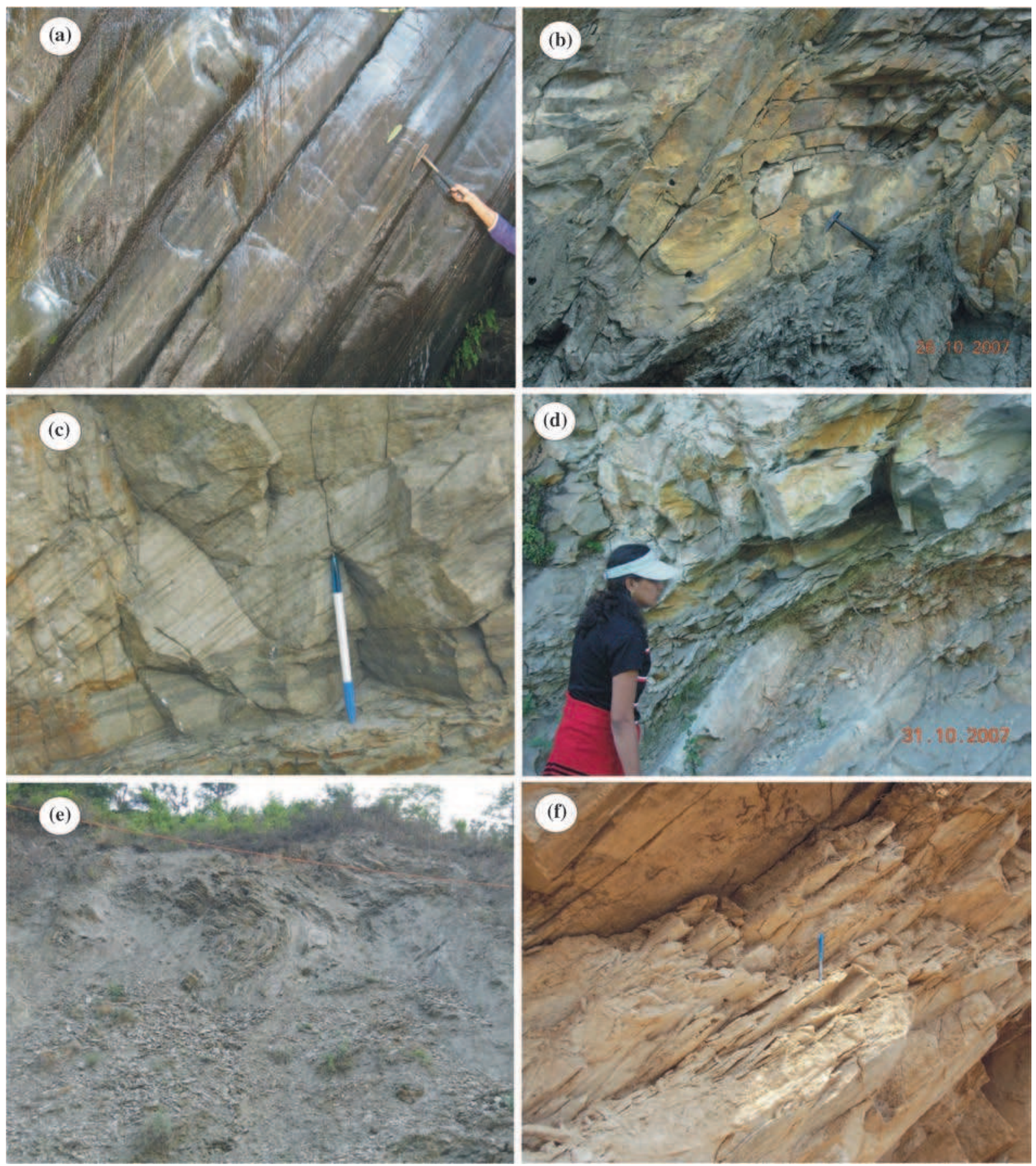

Figure 3. Field photographs of the studied quartzites: (a) Pandukeshwar quartzite showing laminated and well foliated nature at Hanumanchatti, (b) Tapovan quartzite exhibiting folding near the MCT, (c) Berinag quartzite depicting cross bedding preserved near Chamoli, (d) contact between highly fractured Berinag quartzite and mica schist of Nandprayag Klippen, (e) metabasics exbiting crushing due to the Alaknanda Thrust, and (f) highly shattered and mylonitized Berinag quartzite located in the close proximity of the Alaknanda Thrust, south of Tilwara village.

NNW-SSE in the north of the 'Alaknanda Thrust'. The dip amount varies from $25^{\circ}$ to $65^{\circ}$.

\section{Sampling strategy}

The systematic sampling of quartzites was carried out in the Higher Himalaya (Pandukeshwar
Formation), MCT zone (Tapovan Formation) and the Lesser Himalaya (Berinag Formation). Twelve block samples, of which three from the Pandukeshwar quartzite (P1, P2, P3), three from Tapovan quartzite (T1, T2, T3) and six from the Berinag quartzite (B1, B2, B3, B4, B5, B6, ) were collected in the field (figure 2). Of these, B1, B2 and B3 were located near the 'Nandprayag Klippen' and 
B4, B5 and B6 near the 'Alaknanda Thrust'. The sampling locations are depicted in figure 2.

\section{Petrography and microstructures}

The petrographic study of Pandukeshwar, Tapovan and Berinag quartzites reveals that these are composed essentially of the quartz grains with or without minor amount of muscovite, garnet, calcite and opaque as accessory minerals. The petrographic characteristics of each are as follows:

\subsection{Pandukeshwar quartzite}

Pandukeshwar quartzite is essentially composed of highly recrystallized quartz along with muscovite and opaques. It displays a well developed stretching lineation defined by the preferred alignment of muscovite (figure 4a). The size of quartz grains is highly variable ranging from fine to coarsegrained (figure $4 \mathrm{~b}$ ). The smaller quartz grains are mainly formed due to subgrain rotation (SGR) process. At places, grain boundary migration has also been noted. In general, the boundaries of the larger quartz grains are highly irregular, surrounded by smaller subrounded to anhedral quartz grains (figure 4b). Generally larger grains show sweeping undulatory extinction, whereas smaller recrystallized grains show straight extinction. At places, these quartz grains are elongated and are preferentially aligned (figure 4a).

\subsection{Tapovan quartzite}

Tapovan quartzite essentially consists of quartz and muscovite with or without little amount of kyanite, garnet, calcite and euhedral opaque crystal. Quartz grains are coarser, inequigranular with smooth grain boundaries (figure 4c). These quartz grains show typical polygonal texture with grain boundaries meeting at $120^{\circ}$ (figure $4 \mathrm{~d}$ ) resulting from annealing at high temperature, i.e., grain boundary migration process (GBM) followed by grain boundary area reduction. Tiny flakes of muscovite are preferentially aligned (figure 4c).

\subsection{Berinag quartzite-I (around Nandparayag Klippen)}

Berinag quartzite around the Nandprayag Klippen are tightly interlocked displaying 'Foam texture' (figure 4e) with boundaries of quartz grains meeting at triple points at $\sim 120^{\circ}$. The quartzite is deformed, yet still retains some sedimentary structures like graded bedding. These are essentially composed of medium-grained, equigranular, subangular to subrounded quartz. Few detrital grains of zircon, kyanite and opaques and small amount of micaceous matrix and siliceous cement are clustered at some places (figure 4f).

\subsection{Berinag quartzite-II (near Alaknanda Thrust)}

Berinag quartzites near the Alaknanda Thrust display two generations of quartz grains. The primary quartz grains are elongated, coarser and have serrated grain boundaries (figure $4 \mathrm{~g}$ ). These show wavy-undulatory extinction (figure $4 \mathrm{~g}$ ) due to deformation. The secondary quartz grains are tiny, recrystallised and are present around the rim of the primary quartz grains (figure $4 \mathrm{~g}$ ). These smaller grains are formed dominantly due to bulging (BLG) recrystallization process. The localized SGR process is observed in B4 and hence its primary grain size of recrystallised quartz is relatively smaller. The transition between undeformed (ortho-quartzite) to deformed (meta-quartzite) has been observed in B7 which is evident by its irregular undulatory extinction as well as the presence of sericitic matrix (figure $4 \mathrm{~h}$ ).

\section{Methodology}

In order to study the seismic and textural properties of quartzites, block samples were drilled into $2.54 \mathrm{~cm}$ diameter and $\sim 4-5 \mathrm{~cm}$ long cylindrical cores along the visible linear structure. In order to avoid the effect of anisotropy, thin sections were prepared along the length of the cores, i.e., along the foliation.

\subsection{Textural properties}

In order to assess the microstructures in all the quartzites, thin sections were studied with the help of polarizing microscope under the plane polarized light and crossed-nicols. The quantification of various textural properties was carried out using image processing software, Image $\mathrm{J}(1.37 \mathrm{~V})$ developed by Wayne Rasband of the National Institute of Health, USA (http:/rsb.info.nih.gov/ij/). The procedure consists of image acquisition, digitizing, data analysis and output. During image acquisition, a number of pictures of the thin section were captured using a digital camera attached to the microscope without changing the orientation of the slide. In the present work, all the pictures were taken with $5 \mathrm{X}$ objective of the microscope. In each picture, about 120-150 grains of quartz were traced. The data generated are on the (a) area (no. of pixels present within the boundary of grain), 

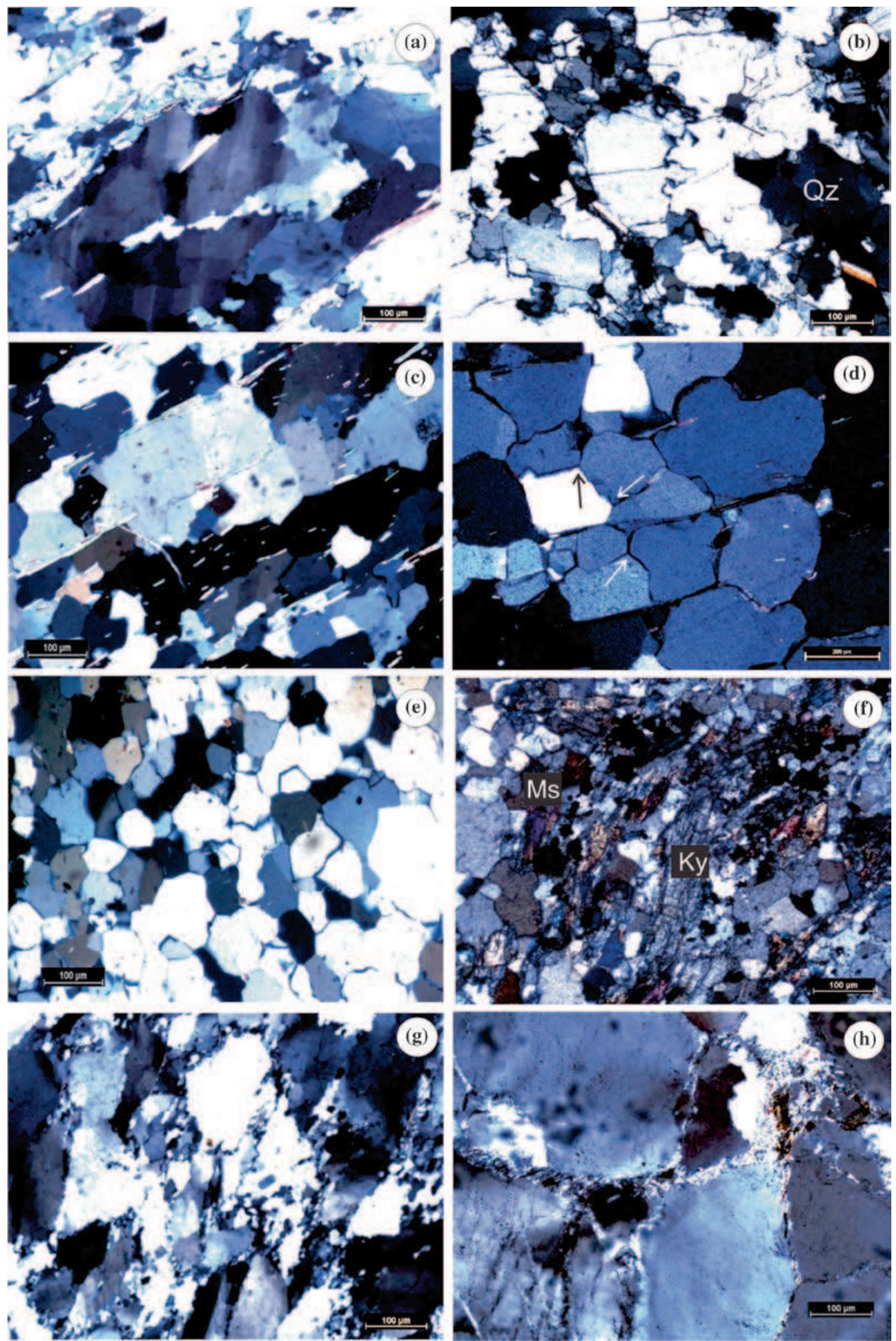

Figure 4. Photomicrographs of various quartzites: (a) subgrain rotation in Pandukeshwar quartzite, relicts of larger old grains with undulose extinction and elongated subgrains within, preferably aligned flakes of muscovite, (b) Pandukeshwar quartzite exhibiting irregular grain boundaries formed due to grain boundary migration, (c) Tapovan quartzite exhibiting pinning structures of quartz grain boundaries on muscovite, (d) Tapovan quartzite exhibiting annealed quartz grains as a result of grain boundary area reduction. Note the quartz grains boundaries meeting at triple point as indicated by arrows. (e) Berinag quartzite-I exhibiting foam texture. Note the equidimentional quartz grains with triple point junction. (f) Berinag quartzite-I showing the clustering of grains of muscovite, kyanite and opaques, (g) Berinag quartzite-II showing primary quartz grain with patchy undulose extinction and serrated grain boundaries surrounded by tiny-secondary quartz grains produced due to bulging recrystallization, and (h) Berinag quartzite-II showing grains of primary quartz embedded in sericitic matrix and exhibiting undulose extinction. 
(b) major axis (no. of pixels adjoining the two points of grain defining the longest axis), (c) minor axis (no. of pixels adjoining the two points of grain defining the shortest axis), and (d) the orientation angle (an angle between the long axis of each grain and a reference axis, i.e., longer axis of the slide). These measured data served for the computation of additional fabric parameters such as aspect ratio, grain boundary suturing and shape preferred orientation which are described below.

\subsubsection{Aspect ratio}

It is defined as the ratio of the major axis $(b)$ to the minor axis $(a)$ of a grain and calculated using the formula

$$
\text { Aspect ratio }=\frac{b}{a} \text {. }
$$

Aspect ratio is one for a perfect circular grain. It increases as the grain gets elongated. The reciprocal of the aspect ratio is also known as 'axial ratio' i.e., $a / b$.

\subsubsection{Grain boundary suturing}

Grain boundary suturing defines the degree of serration of the grain boundary. It is calculated by the area-perimeter method (Lenze and Stockhert 2007) using the formula given below.

$$
\text { Grain boundary suturing }=\frac{r_{1}}{r_{2}}
$$

where $r_{1}$ is radius of the digitized grain. It is equal to perimeter $/ 2 \pi . r_{2}$ is radius of the imaginary circle having an area equivalent to the digitized grain area. It is calculated by $\sqrt{\text { area } / \pi}$. Higher the value of $r_{1} / r_{2}$, higher is the suturing of the grain boundary.

\subsubsection{Shape preferred orientation (SPO)}

Shape preferred orientation (SPO) is defined by the preferred orientation of elongated grains within the rock. There are several methods available to quantify the SPO like $\mathrm{R}_{\mathrm{f}-\Phi}$ method (Ramsay 1967), Paror and Surfor method (Panozzo Heilbronner 1992) and von Mises distribution (Masuda et al. 1999; Piazolo and Passchier 2002). In the present study, von Mises distribution is used to obtain the statistical concentration parameter $(\mathrm{K})$. It is automatically calculated using the excel work sheet of Piazolo and Passchier (2002). The basic input for calculating $\mathrm{K}$ is the orientation angle of major axis of grains in a rock. Higher value of $\mathrm{K}$ implies stronger preferred orientation of minerals. The statistical details about $\mathrm{K}$ is provided by Masuda et al. (1999).

\subsection{Seismic properties}

'Ultrasonic Pulse Transmission' (UPT) technique has been employed for the measurement of seismic wave velocity. In this technique, high energy pulser unit supplies the electric pulse which is transformed into seismic energy by a piezoelectric transmit transducer. The seismic energy travels through the whole length of the cylindrical core, placed between the transmit and the receiving transducers. The pulse is then picked by the receiving transducer which reconverts the seismic wave to an electrical signal and then displays it on the screen of a Cathode Ray Oscilloscope. The initial readings of travel time are picked up from the signal. Both compressional (P-) and shear (S-) wave velocities of the cylindrical cores were calculated by dividing the core length with the travel time. All the measurements were carried out under normal pressure and temperature conditions.

\section{Results}

\subsection{Variation in grain size}

Figure 5 depicts the frequency distribution of grain-size in the present case for all the studied quartzites. In general, it has been observed that Tapovan quartzite and Berinag quartzite-II located in the fault zones are coarser than the rest of the quartzites (table 1 and figure 5). It has been calculated that the median of quartz grain area of the Pandukeshwar quartzite (P1-P3), Tapovan quartzite (T1-T3), Berinag quartzite-I (B1-B3) and Berinag quartzite-II (B4-B6) ranges between $0.11-0.40 \mathrm{~mm}^{2}, 0.26-0.51 \mathrm{~mm}^{2}, 0.08-0.15 \mathrm{~mm}^{2}$ and $0.22-0.57 \mathrm{~mm}^{2}$, respectively. Wide variation in quartz grain area has also been observed in different samples within the same formation. For example, $\sim 94 \%$ quartz grains in $\mathrm{P} 2$ and $\sim 86 \%$ in $\mathrm{P} 3$ exhibit grain area $<0.50 \mathrm{~mm}^{2}$, whereas in $\mathrm{P} 1$, $\sim 50 \%$ of the quartz grains fall in this range. Rest, $\sim 40 \%$ have grain size ranging between 0.40 and $1.2 \mathrm{~mm}^{2}$ and $\sim 10 \%$ have grain size i.e $>1.2 \mathrm{~mm}^{2}$ (figure 5).

The Tapovan quartzites are coarser than the Pandukeshwar quartzites. About 90\% quartz grains in the Tapovan quartzite varies between 0.30 and $0.90 \mathrm{~mm}^{2}$ and $\sim 10 \%$ grains have size $>0.90 \mathrm{~mm}^{2}$. Within the Tapovan quartzites, T2 has restricted grain size $<0.70 \mathrm{~mm}^{2}$, whereas $\mathrm{T} 1$ and T3, it varies up to $2.00 \mathrm{~mm}^{2}$. Berinag quartzite-I is more or less equigranular, has the least variation in quartz grain sizes with $\sim 90 \%$ quartz grains ranging between 0.10 and $0.40 \mathrm{~mm}^{2}$. Within Berinag quartzite-II, B6 is a coarser followed by B5 and B4 (table 1). Large variation in grain size has also been observed in B5 and B6 as compared to B4 

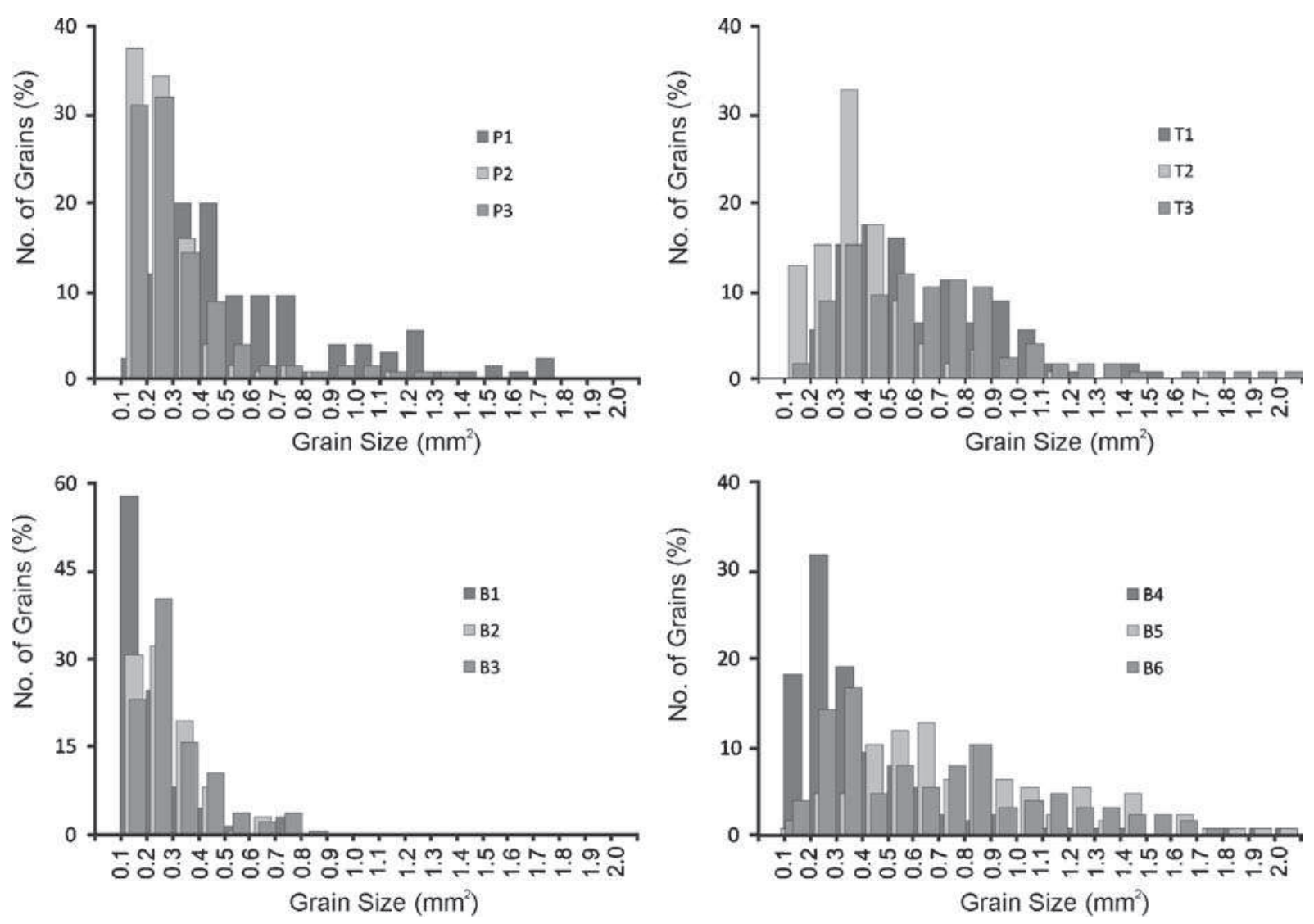

Figure 5. Frequency graph showing the grain size distribution in (a) Pandukeshwar quartzite, (b) Tapovan quartzite, (c) Berinag quartzite-I, and (d) Berinag quartzite-II.

(figure 5). About $75 \%$ quartz grains in B4, $20 \%$ in B5 and $40 \%$ in B6 have grain size $<0.40 \mathrm{~mm}^{2}$, whereas $20 \%$ quartz grains in B4, $50 \%$ in B5 and $35 \%$ in $\mathrm{B} 6$ ranging between 0.40 and $2.00 \mathrm{~mm}^{2}$. It should be noted that B4 and B5 are partially recrystallised and only the margin area of the primary grains is affected by the dynamic recrystallization. Only primary grains are taken into consideration as the secondary grains are too small to trace (figure $4 \mathrm{~g}$ ).

\subsection{Variation in grain shape}

Grain shape is represented either by aspect ratio $(b / a)$ or axial ratio $(a / b)$ that defines the elongation of the grains or the grain boundary suturing $\left(r_{1} / r_{2}\right)$ that defines the irregularity of the grain boundary (figure 6a). In Pandukeshwar, Tapovan and Berinag quartzites (I and II), the median aspect ratio $(b / a)$ varies from $1.48-1.98,1.51-1.71$, 1.45-1.66 and 1.53-1.94, respectively (table 1 ).

It has been observed that within the quartzites of the same formation, the median aspect ratios are highly variable. Within the Pandukeshwar quartzites, P1 and P3 have higher median aspect ratio of 1.98 and 1.82 as compared to $\mathrm{P} 2$ having aspect ratio of 1.48. Within Tapovan quartzites,
T1 exhibits the highest aspect ratio (1.71) followed by T2 (1.51) and T3 (1.52). Within Berinag quartzites-I, B1 having slightly elongated quartz grains, exhibit median aspect ratio of 1.66 , whereas $\mathrm{B} 2$ and B3 exhibit median aspect ratio of 1.59 and 1.45, respectively. Within Berinag quartzites-II, a great variation in aspect ratio has been observed. B4 exhibits the highest median aspect ratio of 1.94, followed by B5 (1.79) and B6 (1.53).

It has further been noted that for Pandukeshwar, Tapovan and Berinag quartzites (I and II), the median grain boundary suturing varies from 1.33$1.66,1.29-1.33,1.17-1.34$ and $1.27-1.38$, respectively (table 1). In general, all the Pandukeshwar quartzites exhibit higher grain boundary suturing indicating highly irregular boundaries. Within the Pandukeshwar quartzites, P1 has the highest (1.66) grain boundary suturing followed by P3 (1.41) and P2 (1.33). Within Tapovan quartzites, Q6, Q8 and Q9 exhibit more or less similar grain boundary suturing varying between 1.29 and 1.33. Within the Berinag quartzites-I, B1 has the highest (1.34) grain boundary suturing, followed by B2 (1.21) and B3 (1.17) (table 1). Within the Berinag quartzitesII, the highest grain boundary suturing is shown by B5 (1.38) followed by B6 (1.31) and B4 (1.27). The data on axial ratio and grain boundary suturing 


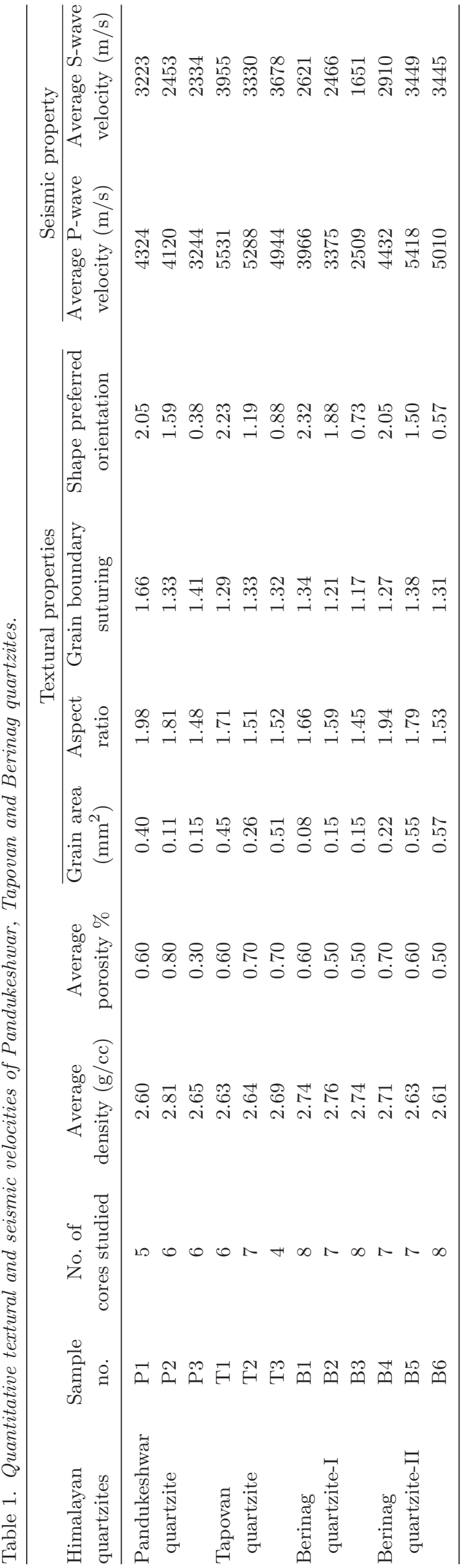

of Pandukeshwar quartzites, Tapovan quartzites and Berinag quartzites (I and II) is plotted in the quartz grain shape boundary diagram (figure 6a) to demonstrate the shape of quartz grains in each sample (figure 6b).

\subsection{Variation in grain orientation}

Figure 7 exhibits the rose plot of the orientation of quartz grains ( $\mathrm{K}$ ) for the Pandukeshwar, Tapovan and Berinag (I and II) quartzites. A large variation in $\mathrm{k}$ has been observed within each group of quartzite. Generally, except P3, all the quartzites show preferred orientation of quartz grains. It has been observed that P1 (Pandukeshwar quartzite), T1 (Tapovan quartzite) and B1 and B4 (Berinag quartzite) display preferred orientation of quartz grains with $\kappa>2.0$, P2 (Pandukeshwar quartzite), T2 (Tapovan quartzite) and B2 and B5 (Berinag quartzite) indicate moderately strong preferred orientation of quartz grains with $\mathrm{k}$ varying between 1.0 and 2.0 (table 1). The rest of the quartzites exhibit $\kappa<1.0$ (table 1 ). It has also been observed that T3, B2, B3 and B6 show second foliation.

\subsection{Variation in seismic ( $P$ - and $S$-waves) velocities}

The variation in $\mathrm{P}$ - and $\mathrm{S}$-wave velocity for all the quartzites is presented in figure 8. Vast variation in the travel times of seismic wave through cores and hence seismic wave velocity have been observed in different groups of studied quartzites (figure 9). Within the Pandukeshwar quartzites, P1 exhibits the highest average $\mathrm{Vp}(4324 \mathrm{~m} / \mathrm{s})$ and $\mathrm{Vs}$ $(3223 \mathrm{~m} / \mathrm{s})$ followed by P2 (4120 and $2453 \mathrm{~m} / \mathrm{s}$ ) and P3 (3244 and $2334 \mathrm{~m} / \mathrm{s})$. Within the Tapovan quartzites, $\mathrm{T} 1$ exhibits the highest average $\mathrm{Vp}$ $(5531 \mathrm{~m} / \mathrm{s})$ and $\mathrm{Vs}(3955 \mathrm{~m} / \mathrm{s})$. The average $\mathrm{Vp}$ and $\mathrm{Vs}$ in T2 and T3 are 5288 and 3330, and 4944 and $3678 \mathrm{~m} / \mathrm{s}$, respectively (table 1 ). Within the Berinag quartzites-I, B1 exhibits the highest average $\mathrm{Vp}(3966 \mathrm{~m} / \mathrm{s})$ and $\mathrm{Vs}(2621 \mathrm{~m} / \mathrm{s})$ followed by B2 $(3375$ and $2466 \mathrm{~m} / \mathrm{s})$ and B3 $(2509$ and $1651 \mathrm{~m} / \mathrm{s})$. Within the Berinag quartzites-II, B5 exhibits the highest average Vp and Vs $(5418$ and $3449 \mathrm{~m} / \mathrm{s}$ ) followed by B6 (5010 and $3445 \mathrm{~m} / \mathrm{s})$ and B4 (4432 and $2910 \mathrm{~m} / \mathrm{s}$ ).

\subsection{Inter-relation between textural parameters and seismic wave velocities}

Figure 10 represents the relationship between various textural parameters and seismic (both P- and S-) wave velocity for all the studied quartzites. It has been observed that both $\mathrm{Vp}$ and $\mathrm{Vs}$ increases with the increase in grain area with a strong 

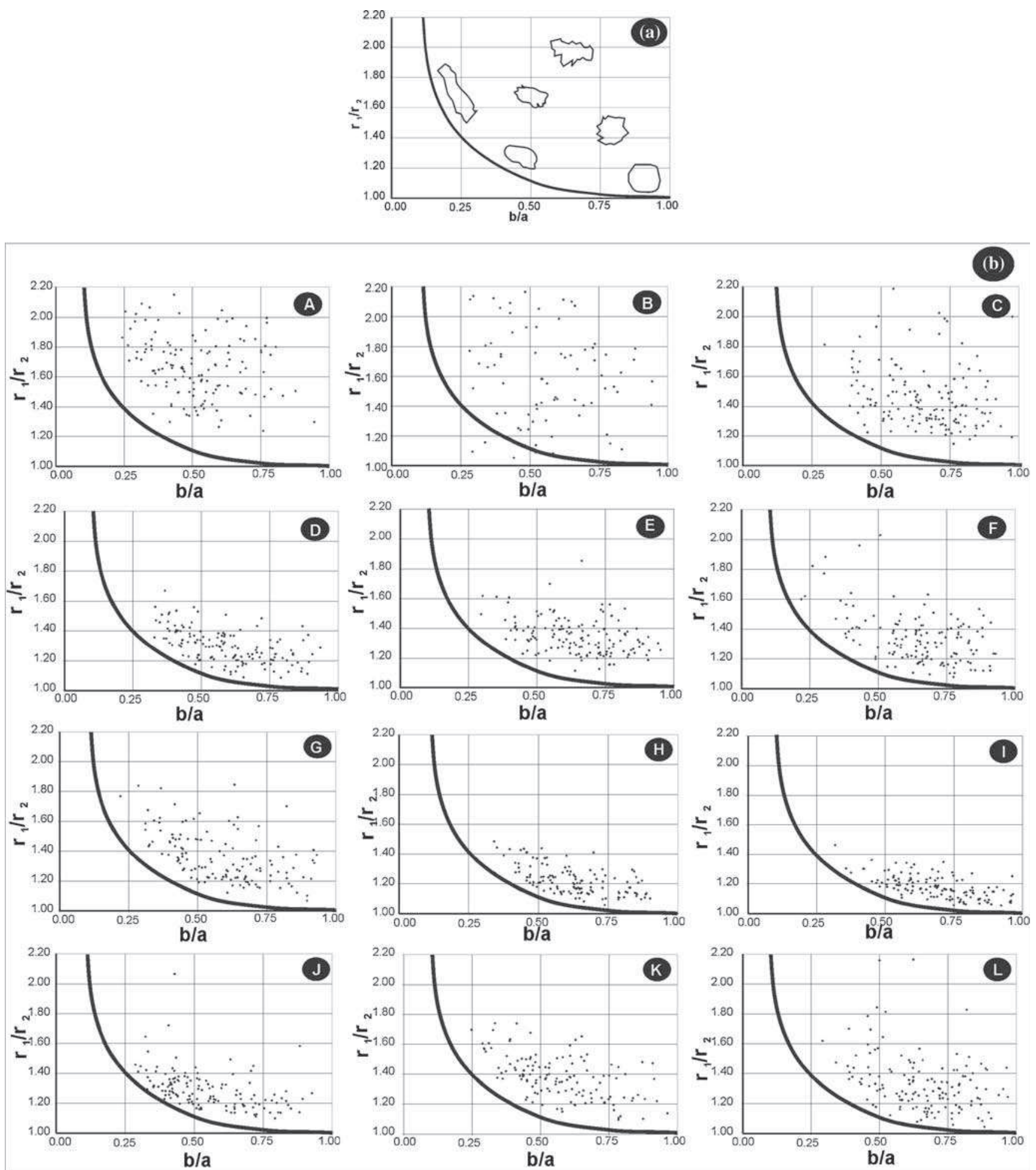

Figure 6. Grain shape diagram visualizing quartz grain shape measured in XY section. (a) X axis indicating the circularityelongation whereas $\mathrm{Y}$ axis indicates the intensity of suturing of mineral boundary, (b) quartz grain shape diagram of Pandukeshwar quartzite (A-C), Tapovan (D-F), Berinag quartzite-I (G-I) and Berinag quartzite-II (J-L).

correlation coefficient $(R)$ of 0.74 for $\mathrm{Vp}$ and 0.82 for Vs (figure 10a). Other textural parameters like aspect ratio (AR), grain boundary suturing $\left(r_{1} / r_{2}\right)$ and shape preferred orientation ( $\mathrm{K}$ ) do not exhibit any meaningful relation with the seismic wave velocity (figure 10b, c and d).

\section{Discussion}

8.1 Development of quartz microstructures/textures in the study area

Wide variation has been observed in the seismic velocities of studied quartzites of the Alaknanda 

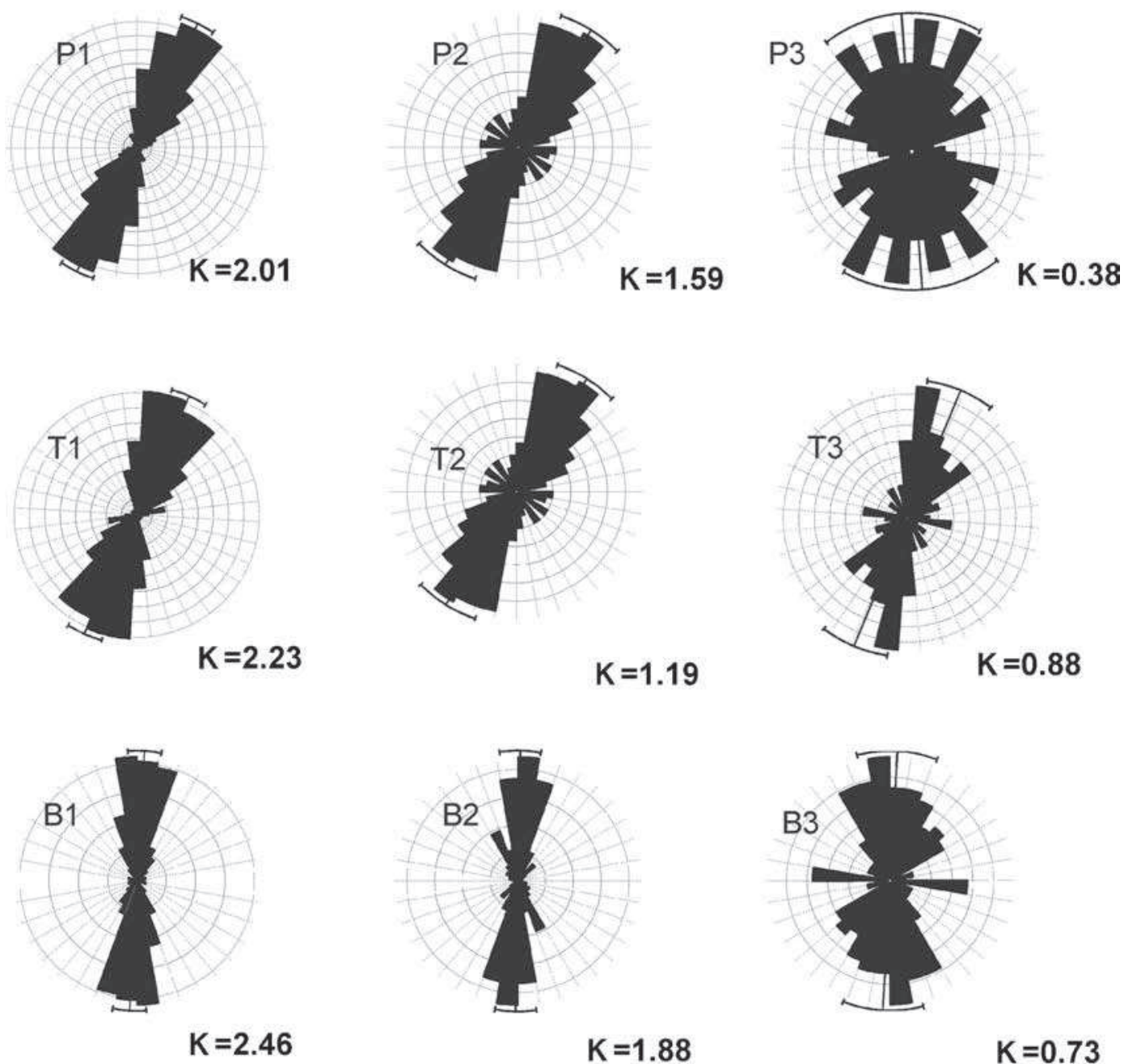

$K=1.88$

$\mathrm{K}=0.73$
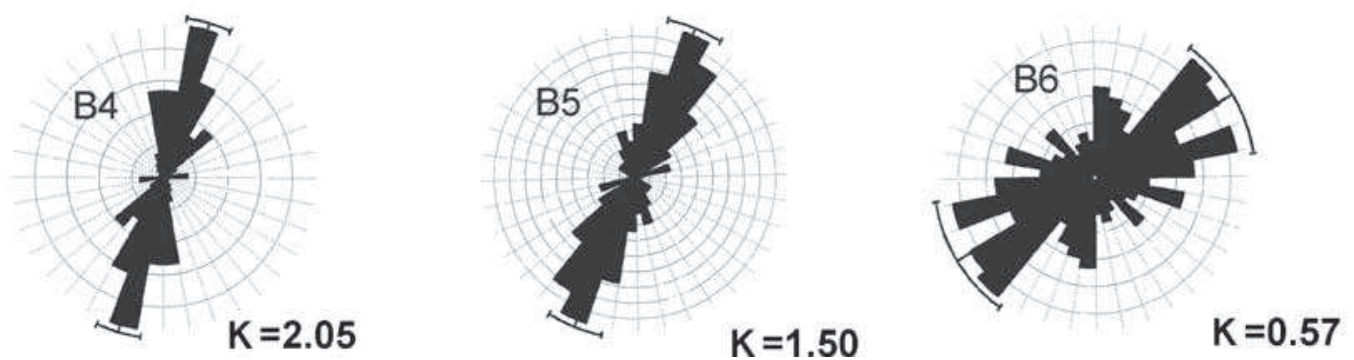

Figure 7. Rose diagram indicating the shape preferred orientation (SPO) of quartz grains in studied samples.

valley. It has well been correlated with the quartzmicrostructures which shows zonal distribution in the area. Grujic et al. (1996) have also observed similar variation in quartz fabric, while working in quartz-tectonics of the Lesser and Higher Himalayas of Bhutan. They summarized that it is the variation in metamorphic conditions that lead to such distinctive quartz-microfabrics.

Furthermore, marked variation in grain size has been observed within the Berinag quartzites (figure 11). The sizes of quartz grains between
Helang and Kaleshwar (Berinag quartzite-I) are noticeably smaller than the quartzites south of Kaleshwar (Berinag quartzite-II). It is expected that the operation of dynamic mechanism probably SGR process during the folding of the Berinag Thrust is responsible for the smaller grain size (figure 11). The larger part of the folded antiform has been eroded, exposing dolomite with bands of phyllite and slate of the Deoban Formation (Celerier et al. 2009). The imprints of deformation such as twinning have also been preserved in dolomite and 

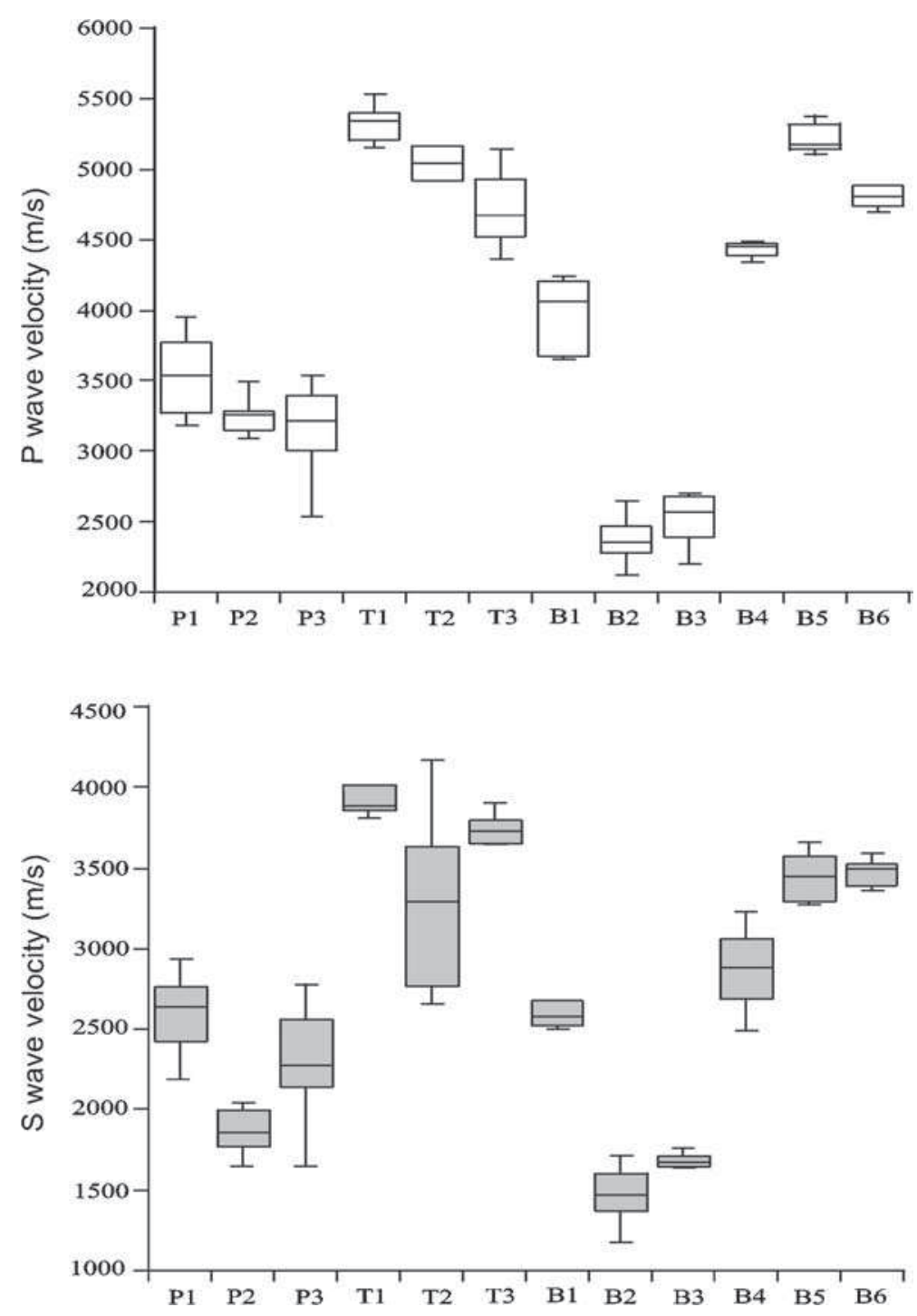

Figure 8. Box plot indicating variation in (a) P-wave velocity and (b) S-wave velocity of the various quartzites.

the presence of recrystallized quartz vein which occurs due to the burial-diagenesis beneath the thrust sheet (figure 12a and b). Probably the movement along MCT has also been activated the Berinag Thrust that reduces grain size of the Berinag quatzites drastically by sub-grain rotation. This has clearly been evidenced in figure 11 .

Berinag quartzite-I around the klippen show the evidences of static recrystallization like equidimentional growth of minerals with straight grain boundary meeting at $120^{\circ}$ and the absence of undulatory extinction (figure 4e). The heat transportation after the emplacement of the Nandprayag Klippen is mainly responsible for static recrysytallization. Also it has been commonly believed that the static recrystallization eliminate the effect of shape preferred orientation (Griggs et al. 1960; Green 1967; Passchier and Trouw 2005). In contrast, B1 and B2 show the preferred orientation, probably due to the relative movement of contrasting lithologies. In our opinion, the preferred orientations could be present at the margins of two different compositions, or formations because of the relative movement between them. This has also been observed in the margin of Pandukeshwar and Tapovan quartzites (table 1 and figure 2). The faster emplacement of the thrust sheet on the surface might have preserved the preferred orientation of the grains even after the process of static recrystalization. According to Otani and Wallis (2006), preferred orientation could not be always obliterated by static recrystallization.

Microstructures of the Berinag quartzite-II around the Alaknanda Thrust exhibit two generations of quartz grains. So far, these structures have been interpreted as a result of bulging recrystallization (BLG) (Stipp et al. 2002) which induces defects in the crystal lattice. These lattice defects are evidenced by undulose extinction under the optical microscope. Further south, far from the area affected by Alaknanda Thrust, undeformed 


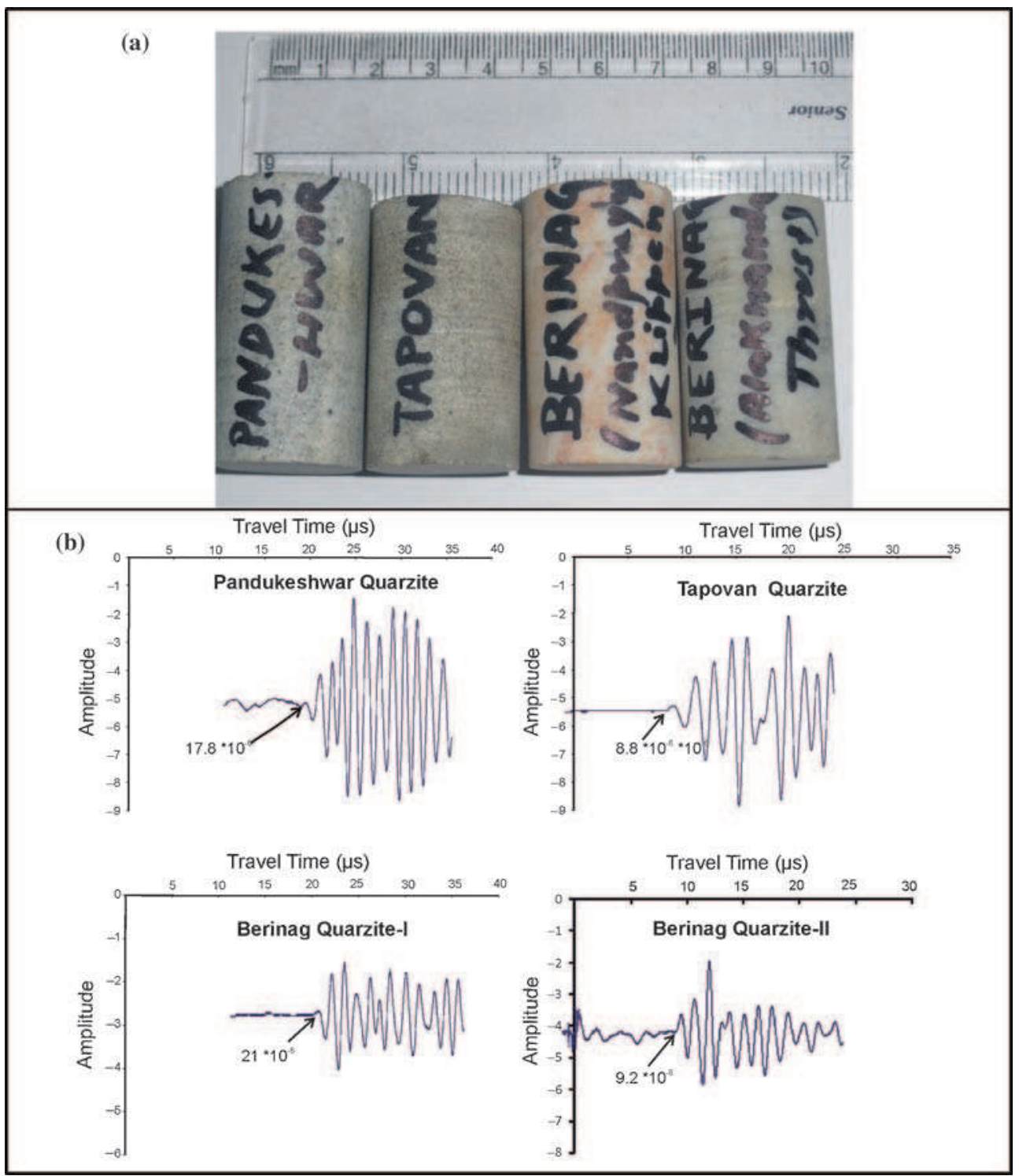

Figure 9. (a) Photograph of core samples of various quartzites. (b) Schematic diagram of the waveforms of test signals for the measurement of seismic velocities in various quartzites using $\mathrm{P}$-wave transducers. Notice the vast difference in travel time although the length of core samples is more or less equal.

quartzite is exposed which consists of rounded detrital grains of quartz (figure 11).

Tapovan quartzite in the MCT zone typically shows homogeneous polygonal texture that is formed due to the operation of GBM, starts at an elevated temperature of $\sim 500^{\circ} \mathrm{C}$ (Stipp et al. 2002). The insignificant shape preferred orientation and homogeneous fabrics of quartz is due to the annealing process.

Pandukeshwar quartzite shows fabric produced primarily due to SGR process (figure 4a) which starts at the temperature of $\sim 400^{\circ} \mathrm{C}$ (Stipp et al. 2002). GBM has also been noted. The vast difference in quartz textures in the quartzites from the Higher Himalaya (Pandukeshwar and Tapovan quartzites) is due to the difference in temperature and strain rate.

\subsection{Control of microstructures over seismic velocities}

It has been noticed that seismic velocities are higher for the quartzites located in the tectonic zones, i.e., Tapovan quartzite and Berinag quartzite-II. The textures of both the quartzites, developed due to different operations of dynamic recrystallization, are significantly dissimilar from one another. Tapovan quartzite exhibits the polygonal textures developed due to the thrust activity along the MCT. According to Bambauer et al. (2009), the effect of dynamic recrystallization on grain-size in a rock is two-fold: (i) BLG and SGR processes responsible for the grain-size reduction in a rock, whereas (ii) GBM followed by grain boundary area reduction is responsible for grain-coarsening. Thus, the coarse grained nature 

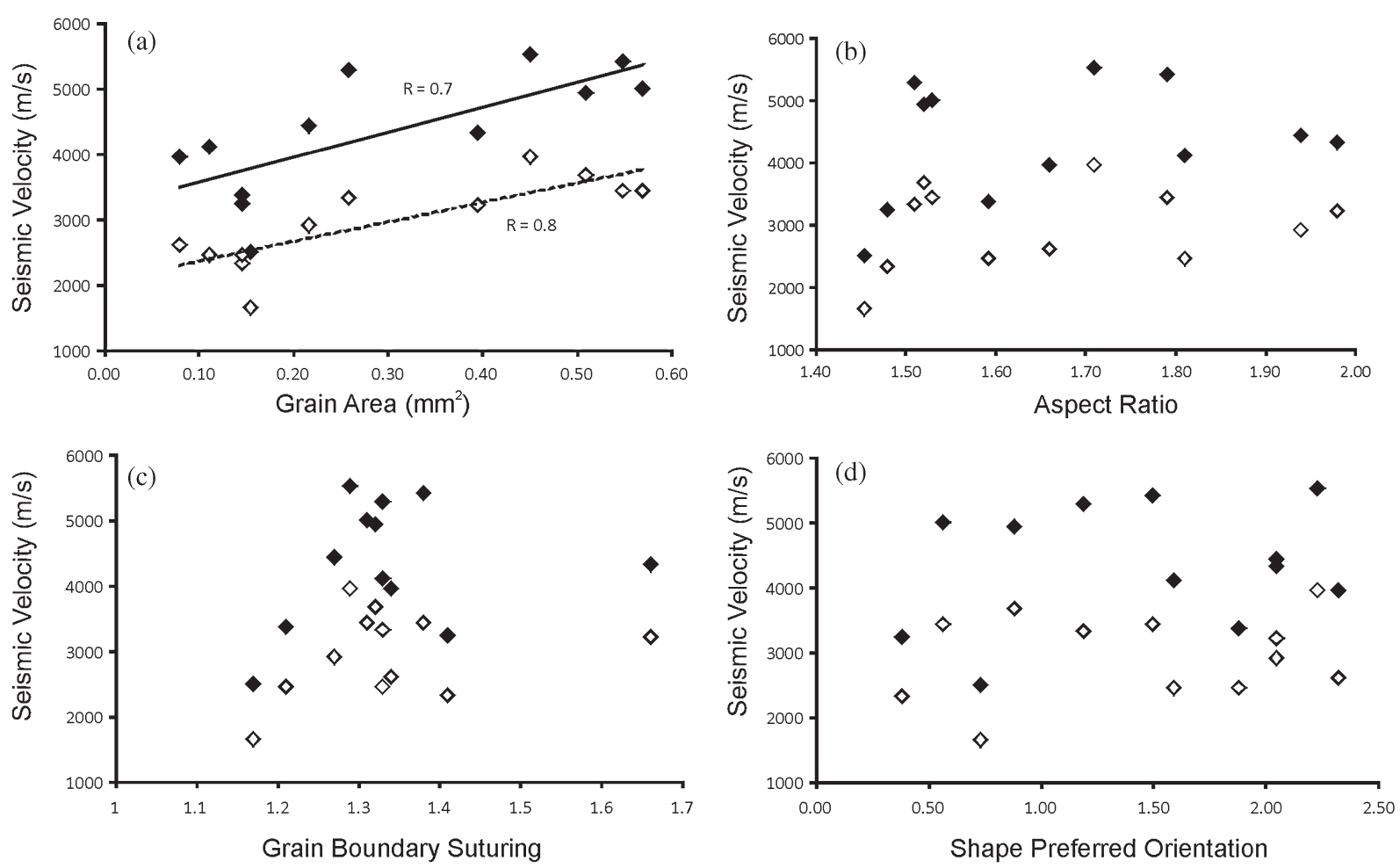

Figure 10. Line graph showing the relationship between quantitative micro-fabric and P- (solid black square) and S- (open black square) wave velocity of various quartzites.

of the Tapovan quartzite is probably the main cause of its higher seismic wave velocity. This is also evident by the positive correlation between grain size and seismic velocity as depicted in figure $10(\mathrm{a})$.

The higher aspect ratio and shape preferred orientation in the Berinag quartzite-II, apart from its coarse grained nature account for its higher seismic velocity. These preferred alignment of ellipitical quartz grains are formed due to the activity of the Alaknanda Thrust. It is a well established fact that the preferred orientation (shape or crystallography) enhances the seismic wave velocity in a rock (Brosch et al. 2000). The Berinag quartzite-I shows the least value of seismic velocity (table 1 and figure 9) due to its relatively smaller quartz grains. The seismic velocity in the Pandukeshwar quartzite is lower than that in the Tapovan quartzite. The microstructure produced in the Pandukeshar quartzite is mainly due to SGR process through which small subgrains are formed, therefore exhibiting large variation in grain sizes (figures 3a, $\mathrm{b}$ and 5). Such large variation in grain sizes is accompanied with higher seismic attenuation as the seismic waves have to traverse through many grain-grain boundaries contact and at each contact, attenuation takes place and thus seismic velocities decreases (Rao et al. 2006; Sharma et al. 2011).
The propagation of seismic waves in rocks is a very complex process which depends on several intrinsic parameters like porosity, cracks, fractures, types and amount of mineral constituents and various textural parameters like grain shape, grain size and grain orientation. All these various rock-fabric parameters are inter-related, hence influences the seismic wave velocity altogether (Gupta and Sharma 2012; Tandon and Gupta 2013). This connotes that it is not possible to predict the exact seismic behaviour of a rock since it drastically changes by the slight variation in one parameter even though the greater part of the rock is composed of a single mineral. Therefore, good relationship between seismic velocity and other textural features, besides the grain size has not been obtained (figure 10b-d).

It is generally accepted that the development of well formed LPO patterns is common in shear zones due to the dominancy of deformation mechanisms (Lister and Williams 1979; Stockhert and Duyster 1999). As a limitation, LPO and CPO studies have not been incorporated in the present study. It is a well known fact that the presence of CPO enhances the seismic velocity in a rock (Ji et al. 2007) and hence could be one of the reasons for a meaningless relationship between seismic velocity and aspect ratio, shape preferred orientation and grain boundary suturing. 


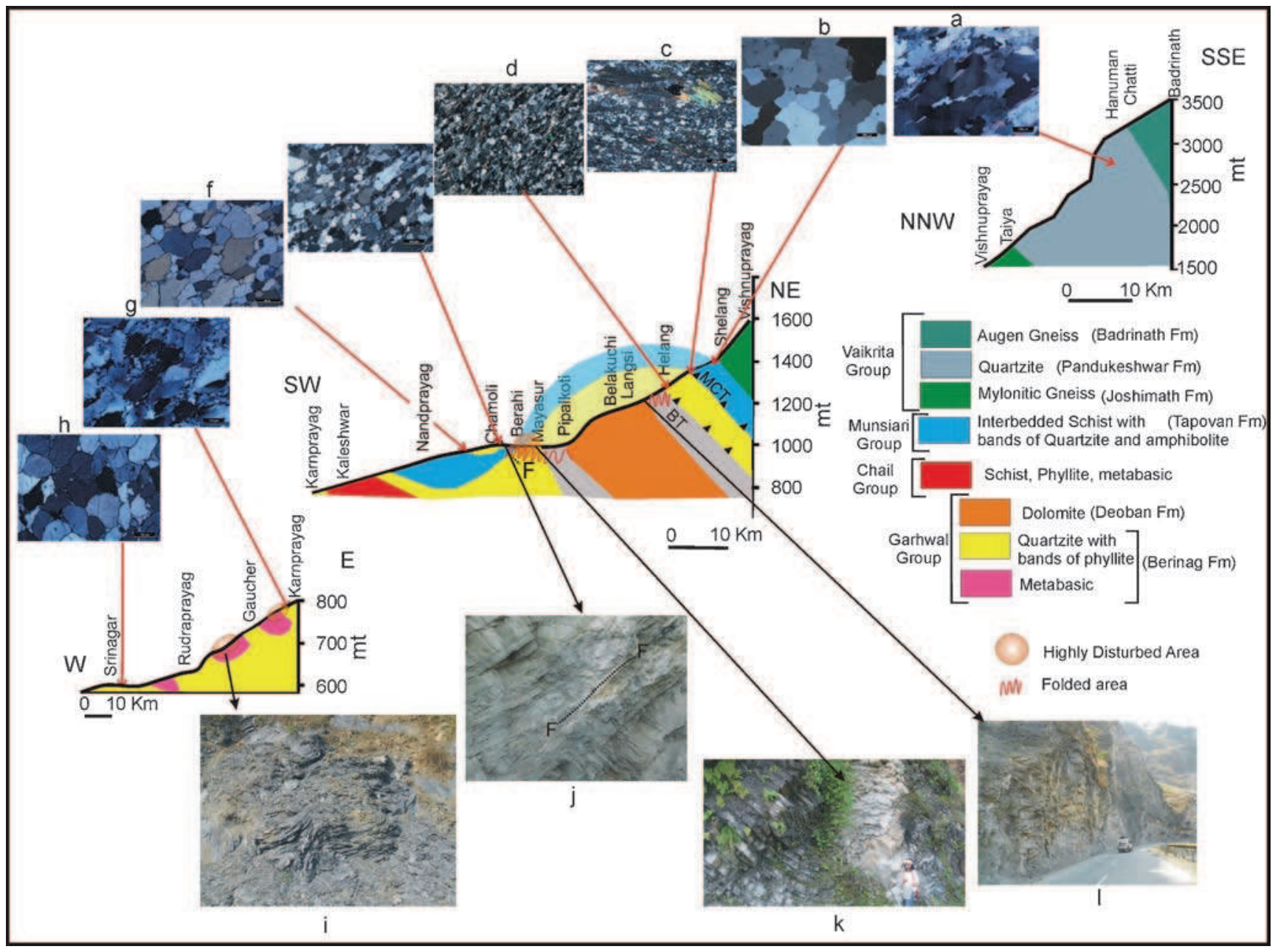

Figure 11. Generalized geological cross section of the study area from Badrinath to Srinagar along with the various photomicrographs and field photographs.
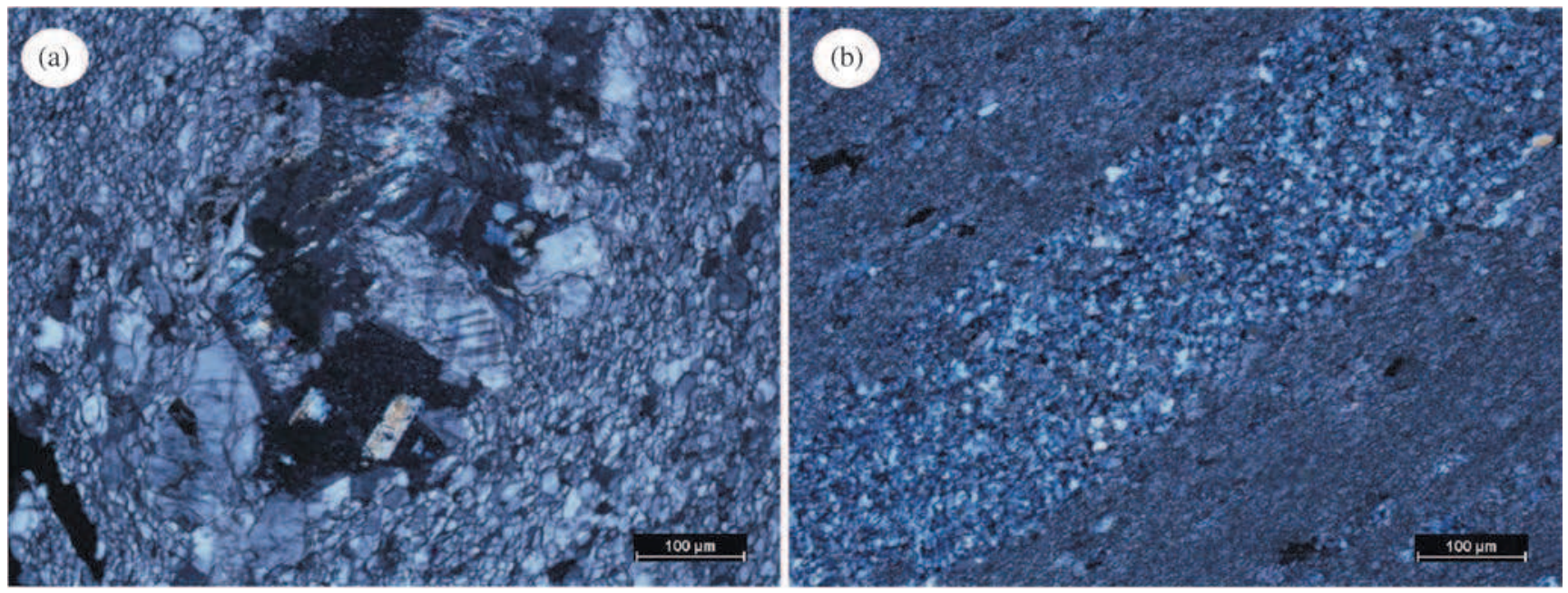

Figure 12. Photomicrographs showing (a) twinning in calcite crystal embedded in dolomitic matrix and (b) recrystallized quartz vein in dolomite. 


\section{Summary and conclusion}

The Alaknanda valley is a unique section to study the quartz micro fabric as it is a natural laboratory that preserves different micro fabric formed due to the operation of different mechanisms of recrystallization and thus has control on the seismic velocities. Hence, this study helps to understand the seismic behaviour of quartzite in different tectonic environment.

The following conclusions have been drawn from the present study:

- Among grain size, grain shape and grain orientation, grain size dominantly controls the seismic wave velocity in quartzites.

- The seismic velocity in the quartzites of tectonic zones, i.e., Tapovan quartzite and BerinagII quartzite is higher than the Pandukeshwar quartzite and Berinag quartzite-I.

- The higher velocity in Tapovan quartzites is due to their coarse-grained nature which has developed due to the thrust activity along the MCT by GBM and grain boundary area reduction, whereas higher velocity in Berinag quartzitesII may be due to their higher aspect ratio and shape preferred orientation produced due to the activity of Alaknanda Thrust.

- The wide variations of grain size in the Pandukeshawar quartzites account for higher attenuation and thus exhibit lower seismic velocity.

- Berinag quartzites-I exhibit the least seismic velocity due to their relatively smaller grain size.

\section{Acknowledgements}

We are grateful to the Director, Wadia Institute of Himalayan Geology, Dehradun for providing all the necessary facilities to carry out the work. The Project Director, National Geotechnical Facility, Dehradun NGF is also thanked for the encouragement and support. Thanks are due to Dr Stipp for his valuable suggestions that improved significantly an earlier version of this manuscript.

\section{References}

Bambauer H U, Herwegh M and Kroll H 2009 Quartz as indicator mineral in the Central Swiss Alps: The quartz recrystallization isograd in the rock series of the northern Aar massif, Swiss; J. Geosci. 102 345-351.

Birch F 1960 The velocity of compressional waves in rocks to 10 kilobars; J. Geophys. Res. 65 1083-1102.

Brosch F J L, Schachner K, Blumel M, Fasching A and Fritz H 2000 Preliminary investigation results on fabrics and related physical properties of an anisotropic gneiss; J. Struct. Geol. 22 1773-1787.

Burke M M and Fountain D M 1990 Seismic properties of rocks from an exposure of extended continental crust - new laboratory measurement from the Ivrea Zone; Tectonophys. 182 119-146.

Celerier J, Harrison T M, Beyssac O, Herman F, Dunlap W J and Webb A G 2009 The Kumaon and Garhwal Lesser Himalaya: Part 1. Structure and Stratigraphy, India; Geol. Soc. Am. Bull. 121 1262-1280.

Christensen N I and Mooney W D 1995 Seismic velocity structure and composition of the continental crust: A global view; J. Geophys. Res. 100(B6) 9761-9788.

Garcia Celma A 1982 Dominal and fabric heterogeneities in the Cap de Creus quartz mylonite; J. Struct. Geol. 44 443-456.

Gogte B S and Ramana Y V 1982 Petrological characteristics and elastic properties of granitoids from major tectonic zones of northwestern Himalaya; Him. Geol. 12 132-155.

Green H 1967 Quartz: Extreme preferred orientation produced by annealing; Science 157 1444-1447.

Griggs D T, Turner F J and Heard H C 1960 Deformation of rocks at 500 to $800^{\circ} \mathrm{C}$; Geol. Soc. Am. Memoir $\mathbf{7 9}$ 39-104.

Grujic D, Casey M, Davidson C, Hollister L S, Kundig R, Pavlis T and Schmid S 1996 Ductile extrusion of the higher Himalaya crystalline in Bhutan: Evidence from quartz microfabric; Tectonophys. 260 21-43.

Gupta V and Sharma R 2012 Relationship between textural, petrophysical and mechanical properties of quartzites: A case study from northwestern Himalaya; Eng. Geol. 135-136 1-9.

Hirth G and Tullis J 1992 Dislocation creep regimes in quartz aggregates; J. Struct. Geol. 14 145-159.

Jackson I and Arculus R J 1984 Laboratory measurements on lower crustal xenolith from Calcuteroo, South Australia; Tectonophys. 101 185-197.

Jessell M W 1987 Grain boundary migration microstructures in a naturally deformed quartzite; J. Struct. Geol. 9 1007-1014

Ji S, Wang Q, Marcotte D, Salisbury M H and Xu Z 2007 $\mathrm{P}$ wave velocities anisotropy and hysteresis in ultrahigh pressure metamorphic rocks as a function of confining pressure; J. Geophys. Res. 112(B09204) 1-24.

Kitamura K, Ishikawa M and Arima M 2003 Petrological model of the northern Izu-Bonin-Mariana arc crust: Constraints from high-pressure measurement of elastic wave velocities of the Tanzawa plutonic rocks, Central Japan; Tectonophys 371 213-221.

Kruhl J H 1996 Prism- and basis-parallel subgrain boundaries in quartz: A micro-structural geothermobarometer; J. Metamor. Geol. 14(5) 581-589.

Lenze A and Stockhert B 2007 Microfabrics of UHP metamorphic granite in the Dora Maira Massif, Western Alps - no evidence of deformation at great depth; J. Metamor. Geol. 25 461-475.

Lister G and Williams P 1979 Fabric development in shear zones: Theoretical and observed phenomena; J. Struct. Geol. 1 283-297.

Masuda T, Kugimiya Y, Aoshima I, Hara Y and Ikei H A 1999 Statistical approach to determination of mineral lineation; J. Struct. Geol. 21 467-472.

Nishimoto S, Ishikawa M, Arima M and Yoshida T 2005 Laboratory measurement of $\mathrm{P}$-wave velocity in crustal and upper mantle xenoliths from Ichino-Megata, NE Japan: Ultrabasic hydrous lower crust beneath the NE Honshu arc; Tectonophys. 396(3-4) 245-259.

Otani M and Wallis S 2006 Quartz lattice preferred orientation patterns and static recrystallization: Natural examples from the Ryoke belt, Japan; Geology 34(7) 561-564.

Panozzo Heilbronner R 1992 The autocorrelation function: An image processing tool for fabric analysis; Tectonophys. $212351-370$. 
Parsons T, Christensen N I and Wilshire H G 1995 Velocities of southern basin and range xenoliths: Insights on the nature of lower crustal reflectivity and composition; Geology 23 129-132.

Passchier C W and Trouw R A J 2005. Microtectonics; 2nd edn, Springer-Verlag, Berlin Heidelberg, Germany.

Piazolo S and Passchier C W 2002 Controls on lineation development in low to medium grade shear zones: a study from the Cap de Creu peninsula. NE Spain; J. Struct. Geol. 24 25-44.

Ramsay J G 1967 Folding and Fracturing of Rocks; McGrawHill Book Company, New York.

Rao M V M S, Prasanna Lakshmi K J, Sharma L P and Chary K B 2006 Elastic properties of granulite facies rocks of Mahabalipuram, Tamilnadu, India; J. Earth Syst. Sci. 115(6) 673-683.

Sharma R, Gupta V, Arora B R and Sen K 2011 Petrophysical properties of the Himalayan granitoids: Implication on composition and source; Tectonophys. 497 23-33.

Stipp M and Kunze K 2008 Dynamic recrystallization near brittle plastic transition in naturally and experimentally deformed quartz aggregates; Tectonophys. 448 77-97.

Stipp M, Stunitz H, Heilbronner R and Schmid S M 2002 The eastern Tonale fault zone: A natural laboratory for crystal plastic deformation of quartz over a temperature range from $250-700^{\circ}$ C; J. Struct. Geol. 24 1861-1884.
Stipp M, Tullis J, Scherwath M and Behrmann J H 2010 A new perspective on Piezometry: Dynamic recrystallized grain size distribution indicate mechanism changes; Geology 38 759-762.

Stöckhert B and Duyster J 1999 Discontinuous grain growth in recrystallised vein quartz-implications for grain boundary structure, grain boundary mobility, crystallographic preferred orientation and stress history; J. Struct. Geol. 21(10) 1477-1490.

Tandon R S and Gupta V 2013 The control of mineral constituents and textural characteristics on the petrophysical and mechanical (PM) properties of different rocks of the Himalaya; Eng. Geol. 153 125-143.

Vernon R H, Johnson S E and Melis E A 2004 Emplacementrelated microstructures in the margin of a deformed pluton: The San José tonalite, Baja California, México; J. Struct. Geol. 26(10) 1867-1884.

White S H 1973 Syntectonic recrystallization and texture development in quartz; Nature 244 276-277.

White S H 1977 Geological significance of recovery and recrystallization processes in quartz; Tectonophys. 39 143-170.

White S H 1979 Grain and sub-grain size variation across a mylonite zone; Contrib. Mineral. Petrol. 70 193-202.

Zappone A, Fernandez M, Garca-Duenas V and Burlini L 2000 Laboratory measurements of seismic P-wave velocities on rocks from Betic chain; Tectonophys. 317 259-272. 